Infrared Absorption Spectra of Steroids

An Atlas. By Konrad Dobriner, E. R. Katzenellenbogen and R. Norman Jones. Pp. xlv +299 . (New York : Interscience Publishers, Inc.; London : Interscience Publishers, Ltd., 1953.) 11.50 dollars.

TSUALLY infra-red spectra are duplicated or printed separately as in the American Petroleum Institute spectra of hydrocarbons, but occasional attempts have been made to provide collected spectra in book form. Nothing comparable with the present atlas in quality of spectra or wide range of comparatively inaccessible compounds has, however, previously appeared. At first sight, the atlas seems highly priced, but since 306 spectra are presented. the cost only works out to about $3 d$. each, which compares favourably with, say, American Petroleum Institute spectra. It is obviously a great convenience to have spectra in book form, neatly classified, and it is probable that in years to come every department of organic chemistry will possess rows of volumes similar to this.

Each spectrum in the atlas has been obtained under the supervision of the authors with 1-5 mgm. of material dissolved in carbon disulphide, carbon tetrachloride or chloroform. By using a double-beam instrument with a variable-length cell in the comparison beam, the solvent absorption has been practically eliminated. The spectral regions covered are $1,800-1,580,1,480-1,300,1,400-650$ and (in twelve cases) $3,700-2,800 \mathrm{~cm}^{-1}$. Even with steroids differing only in some minor point of structure, the spectra are distinct although the spectral differences may be quite small.

This work was started as an aid to cancer research by the late Dr. K. Dobriner. It is a matter of great regret that the death of this investigator has removed a distinguished pioneer from an important field, but this well-laid foundation will certainly be used to great advantage by others.

A. E. Martin

Time Counts

The Story of the Calendar. By Harold Watkins. Pp.xi+ 274. (London : Neville Spearman, Ltd., 1954.) 15s. net.

HE first portion of this book gives a brief history of the calendar up to the time of the introduction of the Gregorian Calendar into Great Britain in 1752. If there is a second edition, the first chapter, which is based on the unacceptable theories of Hoerbiger and Bellamy, should be omitted.

The main part of the book is concerned with the various proposals that have been made for the reform of the Gregorian Calendar and, in particular, with the advantages of the scheme advocated by the World Calendar Association. A proposal in favour of the adoption of the World Calendar has recently been brought before the Economic and Social Council of the United Nations Organization by the Government of India, which is concerned with rectifying the complicated calendar situation in India, where many different calendars are in use; India would like, at the same time, to rerhove the illogicalities and inconveniences of the present calendar.

The Economic and Social Council at its meeting in Geneva at the end of July decided, by a unanimous vote, to refer the question of the reform of the calendar for study by the governments of the world, with the view of its discussion at the nineteenth session of the Council next year.

The fixing of the date of Easter is a separate question. The inconveniences of the date of Faster wandering over a period of thirty-five days are widely felt, and the adoption of the World Calendar would greatly facilitate the fixing of the date of Easter.

H. S. J.

Lower Tertiary Foraminifera of the Qatar Peninsula By Alan Hilder Smout. Pp. ix $+96+15$ plates. (London: British Museum (Natural History).) $45 s$.

7 HE title of this monograph obscures the fact

that it is essentially a study of the Rotaliidea, almost half the contents being devoted to an account of the structure and evolution of the group, tho remainder to systematics. Dr. A. H. Smout demonstrates that the rotaliid test is formed by "instars" of successive laminæ, each of which totally encloses the whole of the previously formed test, so that in Nummulites, for example, the test is constructed from a series of "chinese-box laminæ" and not, as previously thought, from a spiral chevron of shell material.

Evidence from physiology and fossil morphology, influenced by D'Arcy Thompson's "Growth and Form", is synthesized into a persuasive morphogenical argument. Conviction that direct adaptations are possible as a result of physical difficulties imposed on the sarcode by increase in size of the test leads to a limited Neo-Lamarckian interpretation, the author, however, being prepared to allow normal genetical factors to fix and translate the acquired character into the earlier stages of succeeding ontogenies. The systematics are concerned with a revised elassification of the Rotaliidea; the erection of a new superfamily, the Discorbidea ; and a description of rotaliids and a few associated forms from borings in northeast Arabia, including three new genera, Dictyokathina, Kathina and Daviesina, seventeen new species, and two new varieties.

The monograph, which is beautifully printed and illustrated, deserves to be much more widely read than might be expected from its generalized title, since the views expressed are fundamental to adequate appreciation of the structure and morphological evolution of the larger foraminifera.

\section{The Geology of South Africa}

By Dr. Alex. L. du Toit. Edited and prepared for publication by Dr. S. H. Haughton. Third edition, revised and enlarged. Pp. xiv $+611+41$ plates. (Edinburgh and London: Oliver and Boyd, Ltd., 1954.) 63s. net.

THE late Alexander du Toit's "Geology of South Africa" first appeared in 1926 (Nature, 119, $665 ; 1927)$ and was followed by a second edition in 1939. Du Toit himself had almost finished the text of this now revised and enlarged edition at the timo of his death in February 1948. The task of completing the revision, with the aid of certain notes left among the author's papers, and the preparation of the manuscript for the press were placed in the capable hands of Dr. S. H. Haughton.

While the text has been left essentially in the state in which the author prepared it, attention has been directed, by means of footnotes, to later work by South African geologists in which views have been expressed, particularly on problems of correlation, that differ materially from those of the author. The coloured geological map that accompanies the volume has been completely revised and redrawn under Dr. Haughton's supervision. Geologists everywhere will welcome the new edition of this standard and authoritative work. 